\title{
Correlation of sCD40L Level with Force Vital Capacity Value in Restrictive Lung Disease of Systemic Sclerosis Patients
}

\section{SusantoSalim, ${ }^{1}$ Rachmat Gunadi Wachjudi, ${ }^{1}$ Sumartini Dewi ${ }^{1}$}

${ }^{1}$ Internal Medicine Department, Faculty of Medicine, Universitas Padjadjaran, dr. Hasan Sadikin General Hospital

\section{A R T I C L E I N F O \\ Keywords: $\mathrm{SCD} 40 \mathrm{~L}$ \\ Forced Vital Capacity \\ Restrictive Lung Disease \\ Systemic Sclerosis \\ Corresponding author: \\ Susanto Salim MD \\ E-mail address: susantolim84@gmail.com}

All authors have reviewed and approved the final version of the manuscript.

https://doi.org/10.37275/IJR.v10i1.1

\begin{abstract}
A B S T R A C T
Background: Interstitial Lung Disease (ILD) is one of the major cause of morbidity and mortality in Systemic Sclerosis (SSc). The gold standard to diagnose ILD is using High Resolution Computed Tomography (HRCT) scan. HRCT scan need a lot of cost and not always available, so another diagnosing test is needed as an alternative modality to diagnose ILD. ILD is a restrictive lung disease caused by lung fibrosis which is proved by the decrease of Forced Vital Capacity (FVC) in spirometry, and followed by the increase of soluble CD4OL (sCD40L) level in plasma. This SCD40L may become a potential biomarker to evaluate lung fibrosis in SSc patients. The aim of this study is to analyze the correlation of SCD40L levels with FVC score in SSc patients with restrictive lung disease. Method: This cross sectional study was enrolled by the SSc patient who has restrictive lung disease based on spirometry test, at Rheumatology outpatient clinic dr. Hasan Sadikin Hospital from May 2015 to May 2016. All subject took underwent history, physical examination, spirometry and blood test for sCD40L. Data were analyzed using Pearson correlation. Result: There were 38 subjects involved in this study, dominated bywoman $(92.1 \%)$ with mean age $41( \pm 11)$ years. Subjects consist of $22(57,9 \%)$ with limited SSc, $16(42,1 \%)$ with diffuse SSc patients and 33 subjects treated with DMARD. Mean SCD40L serum in this study was $6.690,3( \pm 2.377,3) \mathrm{pg} / \mathrm{mL}$, with no statistical difference between limited and diffuse type $(p=0.154)$. Mean FVC score in this study was $58.2( \pm 10,8)$. There was no significant correlation between $\mathrm{sCD} 40 \mathrm{~L}$ serum with FVC $(\mathrm{r}=0.058 ; \mathrm{p}=0.366)$. There was weak correlation on DMARD naïve subject between $\mathrm{SCD} 40 \mathrm{~L}$ serum and FVC $(r=0.058 ; p=0.366)$ but statistically insignificant. There was no significant correlation between $\mathrm{sCD} 40 \mathrm{~L}$ serum with mRSS $(\mathrm{r}=0,066 ; \mathrm{p}=0,346)$. Conclusion: This study founds no correlation between SCD4OL with FVC in SSc at dr. Hasan Sadikin Hospital.
\end{abstract}

\section{Introduction}

Systemic Sclerosis (SSc) is a chronic progressive autoimmune connective tissue disease that involving many organs. The etiology of this disease is still not well known. ${ }^{1-3}$ Lung is common organ involved in systemic sclerosis patients, such as Interstitial Lung Disease (ILD) and pulmonary arterial hypertension. ${ }^{4}$ Systemic Sclerosis patients suffered with ILD tend to has lower quality of life compared to healthy person. ${ }^{5}$ European Scleroderma Trials and Research (EUSTAR) group reported ILD was a major cause of death in systemic sclerosis. Data of 5800 systemic sclerosis patients showed as much as 35\% deaths caused by pulmonary fibrosis, $26 \%$ by pulmonary arterial hypertension and $4 \%$ by kidney disorder. ${ }^{6}$

ILD is difficult to diagnose, especially in developing country, due to unavailability of High Resolution Computed Tomography (HRCT) scanning which is the gold standard for diagnosing ILD.4,7,8 Moreover, it is not affordable for the most patients. Other pulmonary function tests are more commonly used as initial 
screening of ILD in systemic sclerosis patients in our center.4,7 Those PFT instruments consist of test for diffusing capacity of the lung for carbon monoxide (DLCo), spirometry to define forced vital capacity (FVC), etc. The pulmonary function tests (PFT) play as key role to determine the severity of pulmonary complication in SSc patients. FVC is one of the common test which use to determine the severity of restrictive abnormality in ILD. 8

T-cells trigger fibroblasts activation which causing fibrosis process in systemic sclerosis patients. Activated CD4 T-cells will express CD40 ligand (CD40L/CD154) that binds to CD40 on the surface of the B-cells. T cells will produce cytokines and stimulate fibroblast to start fibrosis cascade as the main pathogenesis of systemic sclerosis. ${ }^{9} \mathrm{CD} 40 \mathrm{~L}$ is suggested playing role in fibrosis cascade. CD40L can be cleaved from the cell surface, releasing a soluble CD40L (sCD40L) which is biologically active. 10,11 Allanore, et al reported an increase of plasma sCDL40 associated with vascular complication in systemic sclerosis patients. Instead, other studies reported controversially role of CD40-CD40L bond in pulmonary fibrosis. ${ }^{11,12}$

Aim of this study is to analyze the correlation of sCD40L level with FVC value in restrictive lung disease of systemic sclerosis patients.

\section{Research Methods}

This cohort retrospective study enrolled the systemic sclerosis patients who had restrictive lung disease based on spirometry test. Data were collected from outpatient subjects at clinic rheumatology, Hasan Sadikin General Hospital from May 2015 to May 2016. The inclusion criteria were patients who diagnosed with systemic sclerosis based on ACR/EULAR 2013 criteria with restrictive lung disorders and willing to participate in this study, includes carried out blood test and spirometry examination. Exclusion criteria were patients who diagnosed with other autoimmune diseases and/or diagnosed with restrictive lung disease other than ILD through history, physical examination and history from previous medical records.

This study used two step of data collection. Initial step was screening to get subjects who meet the inclusion and exclusion criteria. The next step was venous blood sampling to determine the sCD40L level followed by spirometri test to evaluate FVC value. Then data was analyzed with Pearson correlation test.

\section{Results}

We included 38 patients in this study. Characteristics of the subject are shown at table 1.

The median of modified Rodnan Skin Score (mRSS) is 17 and has range 4 to 36 . Mean of FVC by spirometry examination was $58.2+10.8$. The most were $15(40 \%)$ moderate restrictive lung patients, 10 (26\%) severe restrictive lung patients, 8 (21\%) moderate to severe restrictive lung patients, and $5(13 \%)$ mild restrictive lung patients. Mean of sCD40L was $6690.3 \pm 2377.3$ $\mathrm{pg} / \mathrm{mL}$. There were no statistically different of sCD40L level and FVC value between diffuse type and limited type systemic sclerosis subjects.

There was five $(13.2 \%)$ subjects who were for the first time diagnosed as systemic sclerosis and had never taken DMARD treatment before this study. mRSS score was higher in DMARD-naïve patients $(\mathrm{p}=0.036$, Mann-Whitney) sCD40L and FVC had no different between DMARD patients and DMARD-naïve patients shown in table 2.

Bivariate test was used to analyze correlation between sCD4OL level and FVC value revealed that $\mathrm{sCD} 40 \mathrm{~L}$ was not correlated with FVC $\left(\mathrm{r}=0.058, \mathrm{R}^{2}=\right.$ 0.0034, $\mathrm{p}=0.366$, Pearson correlation). Figure 1 show scatter diagram of this study.

There was weak correlation on DMARD naïve subject between sCD40L serum and FVC ( $\mathrm{r}=-0.225$; $\mathrm{p}=0.358$, Pearson correlation) but not significant as shown in table 3. 
Table 1.Characteristics of Subjects

\begin{tabular}{lccc}
\hline \multicolumn{1}{c}{ Characteristics } & $\begin{array}{c}\text { All Subjects } \\
\mathbf{n = 3 8}\end{array}$ & $\begin{array}{c}\text { Limited Type } \\
\mathbf{n = 2 2}(\mathbf{5 7 . 9 \% )}\end{array}$ & $\begin{array}{c}\text { Diffuse Type } \\
\mathbf{n = 1 6} \text { (42.1\%) }\end{array}$ \\
\hline Age (mean \pm SD) years & $41 \pm 11$ & & \\
Sex & & & \\
$\quad$ Male (n\%) & $3(7.9)$ & & \\
$\quad$ Female (n\%) & $35(92.1)$ & & \\
Treatment History & $33(86.8)$ & & \\
$\quad$ Methotrexate (n\%) & $33(86.8)$ & & \\
$\quad$ Steroid (n\%) & $2(5.3)$ & & \\
$\quad$ Cyclophosphamide (n\%) & $5(13.2)$ & & \\
$\quad$ DMARD-naïve (n\%) & $17(4-36)$ & $(10-36)$ \\
mRSS (median, range) & $58.2 \pm 10.8$ & $57,1 \pm 12,7$ & \\
FVC (mean \pm SD) & $6690.3 \pm 2377.3$ & $6218,0 \pm 2170,7$ & $7339,8 \pm 2562,5$ \\
sCD40L (mean \pm SD) & & & \\
(pg/mL) & & & \\
\hline
\end{tabular}

Tabel 2. Difference between DMARD and DMARD-naïve patients

\begin{tabular}{lccc}
\hline \multicolumn{1}{c}{ Variabel } & $\begin{array}{c}\text { DMARD-naive } \\
\mathbf{n = 5}\end{array}$ & $\begin{array}{c}\text { DMARD } \\
\mathbf{n = 3 3}\end{array}$ & p-value \\
\hline mRSS (median, range) & $32(15-36)$ & $14(4-34)$ & $\mathbf{0 . 0 3 6}$ \\
sCD40L (mean $\pm S D$ ) & $5909.8 \pm 783.8$ & $6808.6 \pm 2519.5$ & 0.438 \\
FVC (mean $\pm S D$ ) & $58.4 \pm 9.1$ & $58.1 \pm 11.1$ & 0.958 \\
\hline
\end{tabular}

Figure 1.Scatter diagram between sCD40L and FVC

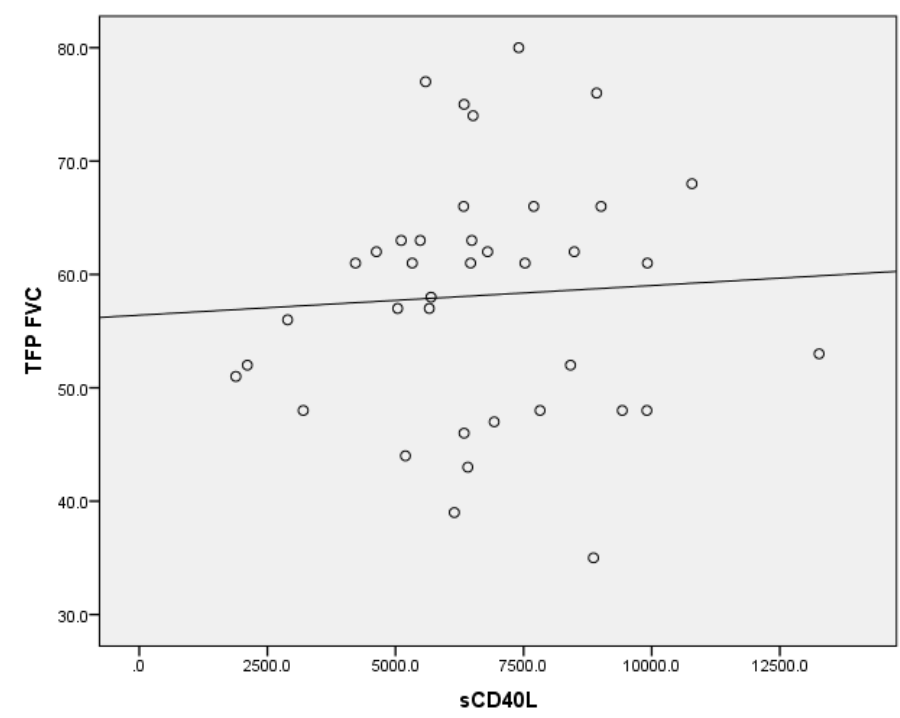

Tabel 4. Bivariate Analysis between sCD40L and FVC in DMARD and DMARD-naïve Patients

\begin{tabular}{|c|c|c|c|}
\hline \multirow{2}{*}{ Variable } & \multirow{2}{*}{ Patients } & \multicolumn{2}{|c|}{ FVC } \\
\hline & & $\mathbf{r}$ & p-value \\
\hline \multirow{2}{*}{ sCD40L } & DMARD-naïve & -0.225 & 0.358 \\
\hline & DMARD & 0.069 & 0.351 \\
\hline
\end{tabular}




\section{DISCUSSION}

Average age of the subjects was $41 \pm 11$ years, it is in accordance with the onset of systemic sclerosis disease which the highest in the fourth and fifth decade.13,14 Mean age was smaller compared to the research conducted by Allanore et al (50 subjects) $57 \pm 11$ years and Komura et al (49 subjects) $51.4 \pm 15.6$ years but in accordance with study on Asian population in Singapore by Low et al (200 subjects), namely $46 \pm 14.9$ years.11,15,16 This difference maybe due to race differences in both populations. So, age of systemic sclerosis patient in Caucasian population is older than in Asian populations.

Most of the subjects were women (92.1\%). These results were differed by the proportion of women and men incidence in US that reached 3-5:1.1,14,17 But, similar to the result obtained by Komura, et al. study in Asia (92\%) and Low research in Singapore (86\%). ${ }^{15,16}$

Mean FVC value by spirometry was $58.2 \pm 10.8 \%$. All subject as restrictive lung disorder that may be a pulmonary fibrosis. There was no difference in FVC value between limited type and diffuse type subjects $(p=0.482)$. Abnormalities of pulmonary fibrosis is more common in diffuse type since it is a rapidly progressing disorder that affects a large area of the skin and compromises one or more internal organs including lung. Expression of antinuclear antibody is more dominant in diffuse type SSc compared to the limited type. 1 FVC examination can be used as an initial screening test but the incidence of pulmonary fibrosis may not be used as the gold standard to diagnosis pulmonary fibrosis.

Mean of sCD40L levels in our study were $6690.3 \pm 2377.3 \mathrm{pg} / \mathrm{mL}$. This is higher when compared with control values in Allanore, et al study (median sCD40L 79 (50-118) pg/mL) and Salibi, et al. study (mean sCD40L $717 \mathrm{pg} / \mathrm{mL}$ ). sCD40L levels in our study is also higher than SCD40L level in systemic sclerosis patients in Allanore, et al. study with a median SCD40L 495 (10-2690) $\mathrm{pg} / \mathrm{mL}$ and Salibi, et al study with a mean sCD40L $1564 \mathrm{pg} / \mathrm{mL} .{ }^{11,18}$ This difference happened due to the difference subjects involved in Allanore, et al study used all systemic sclerosis patients with or without pulmonary complication, while in the Salibi, et al study, the subjects were included the lung fibrosis subjects with any underlying disease. Whereas the subjects in our study were the systemic sclerosis patients with restrictive lung disorders. CD4OL is believed to play role in the fibrosis cascade of systemic sclerosis patients. CD40-CD40L bond between T-cells and B-cells trigger proliferation and differentiation of Bcells into plasma cells and forms a bond autoantibody.19,20 CD40-CD40L activates the proliferation of fibroblasts, produces pro-inflammatory cytokines, and begins fibrosis process. ${ }^{21,22}$ Komura and Fukasawa reported the increase of plasma CD40 protein due to $\mathrm{CD} 40$ expression on fibroblasts surface in systemic sclerosis patients.15,21 CD40L can be cleaved from cell surface and dissolved as a soluble CD40L on plasma that biologically active. 10,23

From our study, we found no statistically correlation between sCD40L level and FVC $(r=0.058$, $\mathrm{R}^{2}=0.0034, \mathrm{p}=0.366$ ). This is consistent with Allanore, et al study that reported lack correlation between sCD40L levels with pulmonary fibrosis and carbon monoxide diffusing capacity ( $\left.\mathrm{DL}_{\mathrm{co}}\right) .{ }^{11}$ Other study by Salibi, et al reported a significantly increasing of sCD40L levels in pulmonary fibrosis patients when compared to the healthy population $(\mathrm{p}<0.05) .{ }^{18}$ Salibi, et al also reported a correlation SCD4OL level with FVC (R2=0.16, $\mathrm{r}=0.4)$ but not significantly related $(\mathrm{p}=0.16) .{ }^{12}$

There are some differences between our study and the study conducted by Allanore, et al or Salibi, et al. This study included 38 subjects while Allanore, et al study followed by 50 subjects and Salibi et al study followed by 13 subjects. This study uses retrospective cohort while the two other studies using cross sectional method. This research together with Salibi, et al analyzed the correlation of SCD4OL levels with the value of FVC, while Allanore, et al analyzed the association of sCD40L levels with the incidence of pulmonary fibrosis and DLco.

Other difference is our study and Allanore, et al study used systemic sclerosis patients, while Salibi, et al. research used all subjects with pulmonary fibrosis. 
Study conducted by Allanore, et al only involve systemic sclerosis patients who have not received immunosuppressive therapy, while in our study, only five subjects who have not received immunosuppressive therapy and the remaining subjects have been treated with methotrexate.

Different level of sCD40L may be affected by several conditions in our subject settings. First, 83.8\% subject has been treated with DMARD (methotrexate, cyclophosphamide). Methotrexate could interfere activation of T-cell that might affect the level of sCD40L. ${ }^{24}$ Second, we measured sCD40L to represent the activity of CD40L, because SCD40L has the CD40L biologic activity. However, there were not any data about the equivalent of SCD40L level on serum and CD40L level on T-cell. Third, many factors could interfere the result of FVC measurement such as age, sex, weight, height, chest abnormality. Fourth, disease activity shown by sCD40L level might fluctuate rapidly while lung damage shown by FVC level might be change in a slow progression.

\section{CONCLUSION}

Our study showed increased plasma soluble CD40 ligand concentrations in restrictive lung disease of systemic sclerosis patients. Our result found no significant correlation between sCD40L with FVC in SSc at dr. Hasan Sadikin General Hospital.

\section{REFERENCES}

1. Gabrielli A, Avvedimento EV, Krieg T. Scleroderma. N Engl J Med. 2009;360(19):19892003.

2. Varga J, Denton CP. Systemic Sclerosis and the Scleroderma-spectrum disorders. In: Firestein GS, Budd RC, Edward D. Harris J, McInnes IB, Ruddy S, Sergent JS, editors. Kelley's Textbook of Rheumatology, $8^{\text {th }}$ ed. Philadelphia: Saunders Elsevier; 2009. p.1311-52.

3. Varga J. Systemic Sclerosis (Scleroderma) and related disorders. In: Kasper DL, Hauser SL, Jameson JL, Fauci AS, Longo DL, Loscalzo J, editors. Harrison's Principles of Internal Medicine, 19th ed. New York: McGraw-Hill; 2015. p. 2154-65.

4. Wells AU, Steen V, Valentini G. Pulmonary complications: one of the most challenging complications of systemic sclerosis. Rheumatology (Oxford, England). 2009;48 Suppl 3: iii40-4.

5. Lumetti F, Barone L, Alfieri C, Silva M, Serra V, Delsante G, et al. Quality of life and functional disability in patients with interstitial lung disease related to Systemic Sclerosis. Acta biomed. 2015;86(2):142-8.

6. Tyndall AJ, Bannert B, Vonk M, Airo P, Cozzi F, Carreira PE, et al. Causes and risk factors for death in systemic sclerosis: a study from the EULAR Scleroderma Trials and Research (EUSTAR) database. Ann Rheum Dis. 2010;69(10):1809-15.

7. Solomon JJ, Olson AL, Fischer A, Bull T, Brown KK, Raghu G. Scleroderma lung disease. Eur Respi Rev. 2013;22(127):6-19.

8. Wells AU, Ward S. Pulmonary Function Tests in Idiopathic Pulmonary Fibrosis. In: C.Meyer K, Nathan SD, editors. Idiopathic Pulmonary Fibrosis. New York: Springer; 2014. p. 103-21.

9. O'Reilly S, Hugle T, van Laar JM. T cells in systemic sclerosis: a reappraisal. Rheumatology (Oxford, England). 2012;51(9):1540-9.

10. Mazzei GJ, Edgerton MD, Losberger C, LecoanetHenchoz S, Graber P, Durandy A, et al. Recombinant soluble trimeric CD40 ligand is biologically active. J Biol Chem. 1995;270(13):7025-8.

11. Allanore Y, Borderie D, Meune C, Lemarechal H, Weber S, Ekindjian OG, et al. Increased plasma soluble CD40 ligand concentrations in systemic sclerosis and association with pulmonary arterial hypertension and digital ulcers. Ann Rheum Dis. 2005;64(3):481-3.

12. Denton CP, Black CM, Korn JH, de Crombrugghe B. Systemic sclerosis: current pathogenetic concepts and future prospects for targeted therapy. Lancet. 1996;347(9013):1453-8.

13. Varga J. Systemic Sclerosis - Epidemiology, Pathology and Pathogenesis. In: Klippel JH, 
Stone JH, Crofford LJ, White PH, editors. Primer on the Rheumatic Diseases, 13 th ed. New York: Springer Science+Business Media; 2008. p. 3518.

14. Komura K, Fujimoto M, Matsushita T, Yanaba K, Kodera M, Kawasuji A, et al. Increased serum soluble CD40 levels in patients with systemic sclerosis. J Rheum. 2007;34(2):353-8.

15. Low A, Gee TG, Giap LW, Cheng NS, Santosa A, Chan G, et al. Disease Characteristics of the Singapore Systemic Sclerosis Cohort. Proceedings of Singapore Healthcare. 2013;22(1):8-14.

16. Mayes MD. Systemic Sclerosis - Clinical features. In: Klippel JH, Stone JH, Crofford LJ, White PH, editors. Primer on the Rheumatic Diseases, $13^{\text {th }}$ ed. New York: Springer Science+Business Media; 2008. p. 343-50.

17. Rami S, Robert MK, Everett P, Richard P, Patricia JS. CD40 Ligand (CD154) Is Elevated In Fibrotic Lung Diseases. B28 Emerging Biomarkers of Complex Lung Diseases. Am J Respir Crit Care Med 185;2012:A2658.

18. Vogel LA, Noelle RJ. CD40 and its crucial role as a member of the TNFR family. Semin Immunol. 1998;10(6):435-42.

19. Baratawidjaja KG, Rengganis I. Sel-sel imun spesifik. In: Baratawidjaja KG, Rengganis I, editors. Imunologi Dasar, 8th ed. Jakarta: Balai Penerbit Fakultas Kedokteran Universitas Indonesia; 2009. p. 93-148.

20. Fukasawa C, Kawaguchi Y, Harigai M, Sugiura T, Takagi K, Kawamoto M, et al. Increased CD40 expression in skin fibroblasts from patients with systemic sclerosis (SSc): Role of CD40-CD154 in the phenotype of SSc fibroblasts. Eur J Immunol. 2003;33(10):2792-800.

21. Sakkas LI, Chikanza IC, Platsoucas CD. Mechanisms of Disease: the role of immune cells in the pathogenesis of systemic sclerosis. Nature clinical practice Rheumatology. 2006;2(12):67985.

22. Pietravalle F, Lecoanet-Henchoz S, Blasey $H$, Aubry JP, Elson G, Edgerton MD, et al. Human native soluble CD4OL is a biologically active trimer, processed inside microsomes. J Biol Chem. 1996;271(11):5965-7.

23. Rami S, Robert MK, Everett P, Richard P, Patricia JS. CD40 Ligand (CD154) Is Elevated In Fibrotic Lung Diseases, But Does Not Predict Severity. B67 Insights into Fibrosis from Translational Studies. Am J Respir Crit Care Med 187;2013:A3372.

24. Manno R, Boin F. Immunotherapy of systemic sclerosis. Immunotherapy. 2010;2(6):863-78. 